Sains Malaysiana 47(3)(2018): 551-562

http://dx.doi.org/10.17576/jsm-2018-4703-16

\title{
Effect of Environment $\times$ Cultivar Interaction on Protein and Mineral Contents of Alfalfa (Medicago sativa L.) in Central Anatolia, Turkey
}

(Kesan Interaksi Alam Sekitar $\times$ Kultivar ke atas Kandungan Protein dan Mineral Alfalfa (Medicago sativa L.) di Anatolia Tengah, Turki)

\author{
ABDULLAH ÖZKÖSE*
}

\begin{abstract}
Nutritive value and persistence of different alfalfa cultivars, but very little information is available in the literature on mineral concentrations, especially on microelements. This study was carried out to determine crude protein and mineral contents in alfalfa cultivars from two different locations, Ankara and Konya provinces, in Central Anatolia during 2005 and 2007. The experiment was conducted using a randomized complete block design with three replications. Significant differences in many investigated traits were found between cultivars, years, locations and location $x$ year, location $x$ cultivar, year $x$ cultivar, and location $x$ year $x$ cultivar interactions. A crude protein ratio and micro and macro element contents ( $K, P, \mathrm{Mg}, \mathrm{Ca}, \mathrm{Mn}, \mathrm{Fe}, \mathrm{Zn}, \mathrm{B}, \mathrm{Mo}, \mathrm{Cu}, \mathrm{Cr}$, Se and $\mathrm{Al})$ were analyzed in alfalfa on a dry weight basis. The results showed that the protein content ranged 17.23 to $20.71 \%$. The macro element contents ranged 2.06 to $3.95 \mathrm{~g} \mathrm{~kg}^{-1}$ for $K, 13.65$ to $23.25 \mathrm{~g} \mathrm{~kg}^{-1}$ for P, 1.31 to $2.53 \mathrm{~g} \mathrm{~kg}^{-1}$ for $\mathrm{Mg}$, 6.71 to $22.81 \mathrm{~g} \mathrm{~kg}^{-1}$ for Ca, and 44.3 to $92.7 \mathrm{mg} \mathrm{kg}^{-1}$ for Fe, whereas the microelement contents ranged 15.4 to $54.3 \mathrm{mg} \mathrm{kg}^{-1}$ for $\mathrm{Mn}, 24.6$ to $121.9 \mathrm{mg} \mathrm{kg}^{-1}$ for $\mathrm{Zn}, 46.4$ to $85.4 \mathrm{mg}$ $\mathrm{kg}^{-1}$ for $\mathrm{B}, 0.50$ to $6.13 \mathrm{mg} \mathrm{kg}^{-1}$ for $\mathrm{Mo}, 3.13$ to $4.17 \mathrm{mg} \mathrm{kg}^{-1}$ for $\mathrm{Cu}, 0.93$ to $2.40 \mathrm{mg} \mathrm{kg}^{-1}$ for Cr, 0.77 to $1.03 \mathrm{mg} \mathrm{kg}^{-1}$ for Se and 31.2 to $57.8 \mathrm{mg} \mathrm{kg}^{-1}$ for Al. Significant differences at the $p<0.01$ or $p<0.05$ level in many investigated traits were found between cultivars, years, locations and location $\times$ year, location $\times$ cultivar, year $\times$ cultivar, and location $\times$ year $\times$ cultivar interactions. In conclusion, due to the fact that the location $\times$ year $\times$ cultivar interaction was found statistically significant, we suggest that appropriate cultivars are selected for each region.
\end{abstract}

Keywords: Alfalfa; location; macro- and microelement; quality

\section{ABSTRAK}

Nutrien dan ketahanan kultivar alfalfa mempunyai nilai berbeza tetapi maklumat yang terdapat dalam kajian perpustakaan mengenai kepekatan mineral terutama pada unsur mikro adalah sangat sedikit. Kajian ini dijalankan untuk menentukan kandungan protein mentah dan mineral dalam kultivar alfalfa dari dua lokasi berbeza iaitu di wilayah Ankara dan Konya, di Anatolia Tengah pada tahun 2005 dan 2007. Uji kaji ini dilakukan dengan menggunakan reka bentuk blok lengkap secara rawak dengan tiga ulangan. Perbezaan penting dalam banyak sifat yang dikaji didapati antara kultivar, tahun, lokasi dan lokasi $x$ tahun, lokasi $x$ kultivar, tahun x kultivar dan lokasi x tahun x interaksi kultivar. Nisbah protein kasar dan kandungan unsur mikro dan makro ( $K, P, M g, C a, M n, F e, Z n, B, M o, C u, C r, S e$ dan Al) dianalisis dalam alfalfa berdasarkan berat kering. Keputusan menunjukkan bahawa kandungan protein berkisar antara 17.23 hingga $20.71 \%$. Kandungan unsur makro berkisar antara 2.06 hingga $3.95 \mathrm{~g} \mathrm{~kg}^{-1}$ untuk $\mathrm{K}, 13.65$ hingga $23.25 \mathrm{~g} \mathrm{~kg}^{-1}$ untuk P, 1.31 hingga $2.53 \mathrm{~g} \mathrm{~kg}^{-1}$ untuk $\mathrm{Mg}$, 6.71 hingga $22.81 \mathrm{~g} \mathrm{~kg}^{-1}$ untuk Ca, dan 44.3 hingga $92.7 \mathrm{mg} \mathrm{kg}^{-1}$ untuk Fe, manakala kandungan elemen mikro berkisar 15.4 hingga $54.3 \mathrm{mg} \mathrm{kg}^{-1}$ untuk Mn, 24.6 hingga $121.9 \mathrm{mg} \mathrm{kg}^{-1}$ untuk Zn, 46.4 hingga $85.4 \mathrm{mg}$

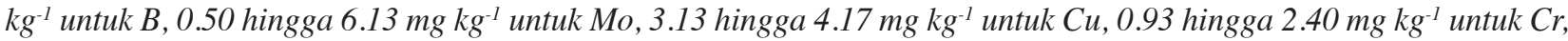
0.77 hingga $1.03 \mathrm{mg} \mathrm{kg}^{-1}$ untuk Se dan 31.2 hingga $57.8 \mathrm{mg} \mathrm{kg}^{-1}$ untuk Al. Perbezaan yang signifikan di tahap p $<0.01$ atau p <0.05 dalam banyak sifat yang dikaji didapati antara kultivar, tahun, lokasi dan lokasi $\times$ tahun, lokasi kultivar, tahun kultivar serta lokasi $\times$ tahun $\times$ interaksi kultivar. Kesimpulannya, lokasi $\times$ tahun $\times$ interaksi kultivasi didapati secara signifikan, kami mencadangkan bahawa kultivar yang sesuai dipilih untuk setiap rantau.

Kata kunci: Alfalfa; kualiti; lokasi ; unsur makro dan mikro

\section{INTRODUCTION}

At present, both global population and consumption per capita of animal products are rapidly increasing. Consequently, the demand for animal products is also increasing. The meadow and pasture fields available cannot satisfy the growing need for animal feeding (Ozkose 2013) without increasing the harvest area, yield and quality of forage crops.

Alfalfa is a valuable forage crop both worldwide and in Turkey, grown for hay and silage. Its importance is due 
to a high nutritious value, perennial longevity, multiple harvests per year, a deep root system, high adaptability to warm and cold climates and the ability to increase soil fertility due to nitrogen fixation (Acar et al. 2011; Avcioglu et al. 2009; Ceylan et al. 2009). Not surprisingly, alfalfa is called a queen of forage crops.

The remarkable adaptability of alfalfa allows it to growing cold region such as Siberia and Alaska in the Northern Hemisphere and in a hot climate of North Africa and the Arabian Peninsula (Avci et al. 2013). It is grown in all regions of Turkey (Tongel \& Ayan 2010). The different regions have different climates, thus alfalfa cultivars grown in each region vary. Therefore, selection of appropriate cultivars is essential.

All plants depend upon soil for their supply of mineral nutrients and grazing ruminant animals obtain the majority of their mineral nutrients from plants grown on these soils (Khan et al. 2006). Minerals make up a small portion of an animal diet; however, they play an important role in animals' health, growth, and reproduction (Lemus 2013). With regard to quality and quantity of plant and animal production, macro and micro minerals need to be optimal levels (Aslan 2017). Forage mineral concentrations are much more variable than those of protein and energy sources (Lemus 2013). Although the crop yield is still the primary economic factor determining the forage crop value per unit of land area, the forage quality has become a close second (Orloff \& Putnam 2007). The quality of alfalfa hay is closely related to its protein and mineral contents (Tongel \& Ayan 2010). The alfalfa hay quality and concentrations of mineral elements in alfalfa can be influenced by factors such as harvesting at specific physiological stages, climatic factors, soil conditions, leaf losses during hay production, storage and feeding practices, diseases and insects, weeds, an alfalfa cultivar, the moisture content during storage, a water supply and fertilizer application (Kahraman 2017; Khan et al. 2006; Orloff \& Putnam 2007; Scholtz et al. 2009).

Numerous studies have been conducted in different regions of the world on a dry matter yield, nutritive value and persistence of different alfalfa cultivars (Orloff \& Putnam 2007), but very little information is available in the literature on mineral concentrations, especially on microelements, in alfalfa cultivars from Central Anatolia, which has a continental climate. Therefore, the aim of this study was to determine protein, macro and microelement contents in the herbage of some alfalfa cultivars grown in Central Anatolia for three years from 2005 to 2007.

\section{MATERIALS AND METHODS}

\section{EXPERIMENTAL SITE, SOIL AND WEATHER CONDITIONS}

This research was conducted in two locations, namely, Konya and Ankara provinces, Central Anatolia Region, Turkey, during 2005-2007.
The research fields in Konya and Ankara provinces are located at $38^{\circ} 02^{\prime} 01.4^{\prime \prime} \mathrm{N}, 32^{\circ} 30^{\prime} 56.4^{\prime \prime} \mathrm{E}$ and $39^{\circ} 50^{\prime} 15.1^{\prime \prime} \mathrm{N}$, $32^{\circ} 25^{\prime} 13.9^{\prime \prime} \mathrm{E}$ and at altitudes of 1,130 and $760 \mathrm{~m}$ above mean sea level, respectively. Soil samples were taken before sowing and analyzed for certain chemical and physical parameters (Table 1). The soil at the experimental area in Konya has a clay loam texture and is slightly alkaline and low in organic matter, while the soil from the Ankara site has a sandy clay texture and is slightly alkaline (Ulgen \& Yurtsever 1974) and low in organic matter according to the Walkley-Black procedure (Kacar 1994).

TABLE 1. Soil characteristics of the experimental area in Konya and Ankara

\begin{tabular}{lll}
\hline \multirow{2}{*}{ Parameters } & \multicolumn{2}{c}{ Values } \\
\cline { 2 - 3 } & Konya & Ankara \\
\hline Clay $(\%)$ & 27.6 & 35.8 \\
Silt & 31.4 & 18.6 \\
Sand & 41.0 & 45.6 \\
Textural class & Clay loam & Sandy clay \\
pH & 7.8 & 7.6 \\
Organic matter $(\%)$ & 1.3 & 1.5 \\
EC ( $\mu$ s cm $\left.{ }^{-1}\right)$ & 181 & 285 \\
$\mathrm{P}_{2} \mathrm{O}_{5}(\mathrm{ppm})$ & 10.74 & 28.66 \\
$\mathrm{~K}_{2} \mathrm{O}(\mathrm{ppm})$ & 227.4 & 286.92 \\
$\mathrm{Zn}(\mathrm{ppm})$ & 6.05 & 1.526 \\
$\mathrm{Fe}(\mathrm{ppm})$ & 2.76 & 6.378 \\
$\mathrm{Cu}(\mathrm{ppm})$ & 0.87 & 1.59 \\
$\mathrm{Mn}(\mathrm{ppm})$ & 3.71 & 15.83 \\
$\mathrm{Ca}(\mathrm{ppm})$ & 6134 & 2765 \\
\hline
\end{tabular}

The climate of the Konya and Ankara provinces can be defined as semiarid continental. The monthly averages of meteorological data during the experimental seasons (October 2005 and September 2007) are provided in Table 2. According to the meteorological data, the long-term (1975-2005) average rainfall is 323.6 and $389.1 \mathrm{~mm}$, the average annual temperature is 11.4 and $11.7^{\circ} \mathrm{C}$ and the average annual relative humidity is 58.0 and $60.5 \%$ in the Konya and Ankara provinces, respectively.

\section{FIELD EXPERIMENT AND PLANT MATERIAL}

The experiment was conducted using a randomized complete block design with three replications. The sowings were made in rows of $5 \mathrm{~m}$ long, with $0.2 \mathrm{~m}$ inter-row space and eight rows per plot. The plot size was $5 \times 1.6 \mathrm{~m}\left(8 \mathrm{~m}^{2}\right)$. Alfalfa was sown for the field trial at the end of September in Konya and at the end of July in Ankara in 2005. The plots were watered after sowing in order to support seedling emergence. In the study, six different alfalfa (M. sativa L.) cultivars (CV) were used as plant material, namely, Kayseri (CV1), Sunter (CV2), Verko (CV3), Hemedan (CV4), Elci (CV5) and Planet (CV6).

Fertilizers were applied to supply $27 \mathrm{~kg} \mathrm{ha}^{-1}$ of nitrogen (N) and $69 \mathrm{~kg} \mathrm{ha}^{-1}$ of phosphorus $\left(\mathrm{P}_{2} \mathrm{O}_{5}\right)$ before sowing and 
TABLE 2. Monthly total rainfall, average temperature and average relative air humidity recorded at Konya and Ankara province during the October 2005 and September 2007 and long years average

\begin{tabular}{|c|c|c|c|c|c|c|c|c|c|c|}
\hline \multirow[t]{2}{*}{ Location } & \multirow[t]{2}{*}{ Mouths } & \multicolumn{3}{|c|}{ Rainfall (mm) } & \multicolumn{3}{|c|}{ Mean air temperature $\left({ }^{\circ} \mathrm{C}\right)$} & \multicolumn{3}{|c|}{ Mean relative air humidity $(\%)$} \\
\hline & & $\begin{array}{l}\text { Long } \\
\text { term }\end{array}$ & $\begin{array}{l}2005- \\
2006\end{array}$ & $\begin{array}{l}2006- \\
2007\end{array}$ & $\begin{array}{l}\text { Long } \\
\text { term }\end{array}$ & $\begin{array}{l}2005- \\
2006\end{array}$ & $\begin{array}{l}2006- \\
2007\end{array}$ & $\begin{array}{c}\text { Long } \\
\text { term }\end{array}$ & $\begin{array}{l}2005- \\
2006\end{array}$ & $\begin{array}{c}2006- \\
2007\end{array}$ \\
\hline \multirow{14}{*}{$\begin{array}{l}\underset{\pi}{\lambda} \\
\stackrel{0}{0} \\
\underline{1}\end{array}$} & October & 32.4 & 34.7 & 66.1 & 12.4 & 10.6 & 13.4 & 59.0 & 71.5 & 68.8 \\
\hline & November & 36.1 & 68.8 & 51.9 & 5.7 & 4.9 & 4.7 & 70.0 & 76.4 & 74.8 \\
\hline & December & 41.4 & 9.8 & 0.1 & 1.4 & 1.5 & -0.2 & 77.0 & 76.6 & 71.8 \\
\hline & January & 34.8 & 21.2 & 20.9 & -0.3 & -2.9 & 2.0 & 76.0 & 80.2 & 64.0 \\
\hline & February & 24.1 & 23.8 & 19.3 & 1.0 & 1.2 & 0.3 & 70.0 & 77.2 & 74.0 \\
\hline & March & 26.5 & 18.4 & 15.4 & 5.4 & 7.1 & 5.7 & 62.0 & 70.2 & 53.0 \\
\hline & April & 39.5 & 53.4 & 16.1 & 10.9 & 12.2 & 9.2 & 58.0 & 61.6 & 57.0 \\
\hline & May & 43.5 & 17.9 & 16.3 & 15.6 & 16.2 & 20.6 & 55.0 & 59.2 & 41.0 \\
\hline & June & 21.9 & 9.9 & 15.9 & 20.1 & 22.0 & 23.3 & 47.0 & 43.4 & 39.0 \\
\hline & July & 7.9 & 0.3 & 0.4 & 23.5 & 23.2 & 26.2 & 42.0 & 45.1 & 28.0 \\
\hline & August & 5.5 & 0.0 & 6.0 & 22.9 & 26.8 & 26.3 & 43.0 & 39.9 & 35.0 \\
\hline & September & 10.0 & 20.0 & 4.1 & 18.6 & 18.2 & 21.3 & 46.0 & 55.0 & 32.0 \\
\hline & Mean & - & - & - & 11.4 & 11.8 & 12.5 & 58.0 & 63.0 & 53.2 \\
\hline & Total & 323.6 & 278.2 & 227.5 & & & & & & \\
\hline \multirow{14}{*}{ 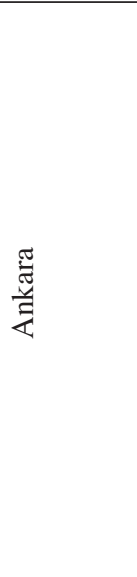 } & October & 26.0 & 28.0 & 37.1 & 12.8 & 10.8 & 13.6 & 58.0 & 66.0 & 70.2 \\
\hline & November & 32.1 & 48.1 & 19.0 & 7.0 & 6.1 & 5.6 & 70.0 & 69.3 & 71.2 \\
\hline & December & 45.9 & 14.4 & 1.3 & 2.4 & 3.0 & 1.1 & 78.0 & 69.8 & 62.8 \\
\hline & January & 39.0 & 35.5 & 39.0 & 0.0 & -1.7 & 1.3 & 76.0 & 73.2 & 76.0 \\
\hline & February & 35.5 & 67.2 & 16.4 & 1.5 & 0.4 & 2.6 & 73.0 & 78.9 & 68.0 \\
\hline & March & 36.8 & 40.4 & 37.5 & 5.6 & 7.5 & 7.3 & 65.0 & 64.0 & 59.0 \\
\hline & April & 43.9 & 29.4 & 23.8 & 11.1 & 13.1 & 9.1 & 59.0 & 55.1 & 53.0 \\
\hline & May & 52.0 & 29.5 & 17.9 & 15.8 & 16.6 & 20.4 & 58.0 & 57.8 & 41.0 \\
\hline & June & 34.2 & 31.8 & 31.7 & 19.8 & 21.6 & 22.5 & 52.0 & 53.1 & 39.0 \\
\hline & July & 15.1 & 2.2 & 3.9 & 23.2 & 23 & 26.7 & 45.0 & 49.2 & 29.0 \\
\hline & August & 11.3 & 0.1 & 9.8 & 23.0 & 27.2 & 26.3 & 44.0 & 44.7 & 37.0 \\
\hline & September & 17.3 & 78.3 & 0.0 & 18.5 & 18.2 & 20.7 & 48.0 & 58.0 & 35.0 \\
\hline & Mean & - & - & - & 11.7 & 12.2 & 13.1 & 60.5 & 61.6 & 53.4 \\
\hline & Total & 389.1 & 404.9 & 237.4 & - & - & - & - & - & - \\
\hline
\end{tabular}

$80 \mathrm{~kg} \mathrm{ha}^{-1}$ of phosphorus in the second and third years. In both the locations, irrigation was applied two times per cutting, before and after cutting, by a sprinkler irrigation method for two years. When the plant is in the $1 / 10$ bloom stage, the plants were harvested on May 24, July 10,August 18 , September 25 in 2006, May 23, July 02, August 08, September 10 in 2007 in Konya; May 21, July 08, August 16, September 24 in 2006, May 20, July 01, August 05, September 09 in 2007 in Ankara. The total yield of four cuttings was used for analysis of protein and macro- and microelements.

After harvest, samples of alfalfa cultivars were prepared for each plot. The samples were dried in a forced oven at $70^{\circ} \mathrm{C}$ to constant dry weight to determine the moisture content (Aydin \& Tosun 1991).

\section{DETERMINATION OF PROTEIN CONTENT}

The protein content of the samples was determined by the Kjeldahl method using a Kjeldahl device (AACC 1990). A crude protein ratio was calculated by multiplying the nitrogen concentration by 6.25 (Kacar 1972).

\section{DETERMINATION OF MINERAL CONTENTS}

About $0.5 \mathrm{~g}$ of a dried and ground sample was put into a burning cup and $2 \mathrm{~mL}$ of $35 \% \mathrm{H}_{2} \mathrm{O}_{2}$ and $5 \mathrm{~mL}$ of $65 \%$ $\mathrm{HNO}_{3}$ were added. The sample was incinerated in a MARS 5 microwave oven at $180^{\circ} \mathrm{C}$ and the residue was dissolved in a certain volume of distilled water (Acar et al. 2012; Ozcan 2004). Mineral concentrations were determined by ICP-OES (PerkinElmer Optima DV 2000), as per instructions of the manufacturer. The values obtained are being expressed as $\%, \mathrm{~g} \mathrm{~kg}^{-1}$ or $\mathrm{mg} \mathrm{kg}^{-1}$ of dry matter.

\section{STATISTICAL ANALYSIS}

The data obtained were analyzed by a randomized complete block model ANOVA. The significance levels ranged $p=$ $0.05-0.01$ for statistical analyses. Differences between means were assessed with the Least Significant Difference (LSD) test at $p=0.01$ or 0.05 levels of significance. Statistical analyses were performed using the MSTAT-C statistical software package. 


\section{RESULTS AND DISCUSSION}

In this research, six alfalfa (M. sativa L.) cultivars were studied in two different locations for two years. The results obtained by the variance analysis for all characteristics studied are summarized in Table 3 . The results showed that the protein and mineral contents of alfalfa cultivars ranged widely with regard to the most study parameters.

\section{PROTEIN CONTENT}

The results of the variance analysis showed that the protein content in alfalfa hay was significantly affected by the location $(p<0.05)$ and by the cultivar $(p<0.01)$, as well as by such interactions as year $\times$ cultivar $(p<0.01)$ and location $\times$ year $\times$ cultivar $(p<0.01)$. However, no statistically significant differences were found for the year and location $\times$ year and location $\times$ cultivar interactions (Table 3 ).

The mean protein content was greater in Ankara province $(19.36 \%)$ than in Konya (18.48\%). The protein contents of alfalfa cultivars were found to vary between $17.99 \%$ for CV2 and $19.52 \%$ for CV6. In terms of the year $\times$ cultivar interaction, the protein content varied between $17.25 \%$ for CV2 in 2006 and $19.75 \%$ for CV6 in 2007. For the year $\times$ location $\times$ cultivar interaction, the highest protein content $(20.71 \%$ ) was obtained for CV4 in Ankara in 2007, while the lowest value $(16.07 \%)$ was found for CV2 in Konya in 2006 (Table 4).

Akca Pelen et al. (2013) registered protein contents of 13 to $20.4 \%$ for 32 alfalfa cultivars from 2002 to 2012 . Karadag et al. (2011) found that protein contents were different among alfalfa cultivars and varied between 14.36 and $17.78 \%$. Sabanc1 et al. (2013) mentioned that protein contents of alfalfa cultivars differed depending on the year and ranged 16.79 to $19.49 \%$ for different years. The findings of this study were similar to the above results. Smith (1969) showed that alfalfa grown in a warm regime $\left(32^{\circ} \mathrm{C}\right.$ day $/ 24^{\circ} \mathrm{C}$ night $)$ had a higher protein content than that grown in a cool regime $\left(18^{\circ} \mathrm{C}\right.$ day $/ 10^{\circ} \mathrm{C}$ night). Protein contents of alfalfa varied depending on agricultural practices such as a harvesting stage (Collins \& Taylor 1980), soil type, stage of growth (Wedin et al. 1956), inter-row space, fertilization (Haby et al. 1999), the temperature (Smith 1969) and also dormancy groups of alfalfa cultivars. In this study, the protein content differed depending on the location, cultivar, year $\times$ cultivar and location $\times$ year $\times$ cultivar interactions.

\section{PHOSPHORUS (P) CONTENT}

In this study, we found that the differences in the $\mathrm{P}$ content of alfalfa hay were statistically highly significant $(p<0.01)$ between the locations, years, cultivars and location $\times$ year, location $\times$ cultivar, year $\times$ cultivar and location $\times$ year $\times$ cultivar interactions (Table 3 ).

The P content was greater for Ankara $\left(2.98 \mathrm{~g} \mathrm{~kg}^{-1}\right)$ than for Konya $\left(2.40 \mathrm{~g} \mathrm{~kg}^{-1}\right)$. The P content in 2006 was $2.40 \mathrm{~g} \mathrm{~kg}^{-1}$, but in 2007 it was $2.98 \mathrm{~g} \mathrm{~kg}^{-1}$. Among the cultivars, the highest $\mathrm{P}$ content $\left(2.98 \mathrm{~g} \mathrm{~kg}^{-1}\right)$ was found in CV6 and the lowest P content $\left(2.45 \mathrm{~g} \mathrm{~kg}^{-1}\right)$ was found in CV4. In terms of the location $\times$ year interaction, the $\mathrm{P}$ content ranged $2.28 \mathrm{~g} \mathrm{~kg}^{-1}$ in Konya in 2006 to $3.43 \mathrm{~g} \mathrm{~kg}^{-1}$ in Ankara in 2007. The location $\times$ cultivar interaction affected the P content, which varied from 2.29 $\mathrm{g} \mathrm{kg}^{-1}$ for CV1 in Konya to $3.39 \mathrm{~g} \mathrm{~kg}^{-1}$ for CV6 in Ankara. Considering the year $\times$ cultivar interaction, the $P$ content ranged $2.20 \mathrm{~g} \mathrm{~kg}^{-1}$ for $\mathrm{CV} 2$ in 2006 to $3.32 \mathrm{~g} \mathrm{~kg}^{-1}$ for CV6 in 2007. Lastly, for the location $\times$ year $\times$ cultivar interaction the lowest $\mathrm{P}$ content $\left(2.06 \mathrm{~g} \mathrm{~kg}^{-1}\right)$ was obtained for $\mathrm{CV} 4$ in Konya during 2006 growing season, while the highest P content (3.95 $\mathrm{g} \mathrm{kg}^{-1}$ ) was obtained for CV6 in Ankara during 2007 growing season (Table 4).

Collins and Taylor (1980) mentioned that, depending on the soil type $\mathrm{P}$ and lime in soil, the $\mathrm{P}$ content in alfalfa hay ranged 0.23 to $0.39 \%$. In a study conducted by Collins and Taylor (1980) determining the influence of temperature on the yield and a chemical composition of Vernal alfalfa, it was found that the P content varied from 0.24 to $0.34 \%$. Kacar (1972) mentioned that under normal agricultural conditions the amount of $\mathrm{P}$ in alfalfa varied less widely than the amounts of most other elements. It is rather unusual to obtain $\mathrm{P}$ values outside the range of 0.2 to $0.5 \%$, although very low concentrations can occur in alfalfa growing on very deficient soils (Kacar 1972). The $\mathrm{P}$ content range for alfalfa hay obtained in this study is in agreement with the values reported earlier.

\section{POTASSIUM (K) CONTENT}

The results of the statistical analysis showed highly significant differences $(p<0.01)$ between the years (Table 3 ). The potassium content was $15.42 \mathrm{~g} \mathrm{~kg}^{-1}$ in 2006 and $19.10 \mathrm{~g} \mathrm{~kg}^{-1}$ in 2007 (Table 4). Also, the effect of the location on the potassium content was significant $(p<0.01)$. The highest potassium content $\left(17.77 \mathrm{~g} \mathrm{~kg}^{-1}\right)$ was obtained in the Ankara province. With regard to the year $\times$ location interaction $(p<0.01)$, the highest potassium content $\left(21.74 \mathrm{~g} \mathrm{~kg}^{-1}\right.$ ) was found in Ankara in 2007. There were statistically significant differences $(p<0.01)$ in the potassium content between the cultivars. CV6 gave the highest $\left(17.78 \mathrm{~g} \mathrm{~kg}^{-1}\right)$ potassium content, while the lowest value $\left(16.17 \mathrm{~g} \mathrm{~kg}^{-1}\right)$ was obtained for CV4. The effect of the year $\times$ cultivar interaction on the $\mathrm{K}$ content in alfalfa hay was highly significant $(p<0.01)$, with the values ranging $14.56 \mathrm{~g} \mathrm{~kg}^{-1}$ (CV4 in 2006) to $19.95 \mathrm{~g} \mathrm{~kg}^{-1}$ (CV5 in 2007). The $\mathrm{K}$ contents in alfalfa hay were significantly affected by the location $\times$ year $\times$ cultivar interaction $(p<0.01)$ and the highest $\mathrm{K}$ content $\left(23.25 \mathrm{~g} \mathrm{~kg}^{-1}\right)$ was obtained for CV5 in Ankara during 2007 growing season. Turan et al. (2010) indicated that boron application increased tissue $\mathrm{K}$ accumulation and the $\mathrm{K}$ content ranged 16 to $38 \mathrm{~g} \mathrm{~kg}^{-1}$. Tongel and Ayan (2010) mentioned that the K content of alfalfa varied from 2.96 to $5.83 \%$. Scholtz et al. (2009) found the $\mathrm{K}$ content to vary between 10.6 and $42.7 \mathrm{~g} \mathrm{~kg}^{-1}$ in 168 South African alfalfa hay samples. Kacar (1972) indicated that over a 2-year period $\mathrm{K}$ values ranged 1.98 to $3.23 \%$. When compared with other published data on the $\mathrm{K}$ 
content of alfalfa hay, the results of the present study were generally similar. The differences could be partly explained by genotypic differences, the vegetative parts used, a stage of maturity, levels of available $\mathrm{Cu}$ in the soil and soil $\mathrm{pH}$ (Khan et al. 2006). Animals need K for milk production, body fluid retention, nerve impulse transmission, muscle contraction and the maintenance of enzyme systems (Lemus 2013) and the recommended levels of $\mathrm{K}$ for all forages are over $8 \mathrm{~g} \mathrm{~kg}^{-1}$ for grazing animals (Underwood 1981). Potassium is the most abundant mineral element in alfalfa and is usually present in a sufficient quantity for animals.

\section{MAGNESIUM (MG) CONTENT}

The differences in the magnesium content were highly significant $(p<0.01)$ between the years (Table 3$)$. The magnesium content was $2.06 \mathrm{~g} \mathrm{~kg}^{-1}$ in 2006 and $1.88 \mathrm{~g} \mathrm{~kg}^{-1}$ in 2007 (Table 4). The location effect on the magnesium content was also highly significant $(p<0.01)$. The highest magnesium content $\left(2.08 \mathrm{~g} \mathrm{~kg}^{-1}\right)$ was obtained for Konya. The effect of the cultivars on the magnesium content was highly significant $(p<0.01)$. The magnesium content was higher in CV5 $\left(2.16 \mathrm{~g} \mathrm{~kg}^{-1}\right)$ than in the other cultivars. Also, the effects of the location $\times$ year, location $\times$ cultivar, year $x$ cultivar and location $x$ year $\times$ cultivar interactions were highly significant $(p<0.01)$. The highest $\mathrm{Mg}$ contents for the location $\times$ year, location $\times$ cultivar, year $\times$ cultivar, and location $\times$ year $\times$ cultivar interactions were found to be $2.22 \mathrm{~g} \mathrm{~kg}^{-1}$ (Konya 2007), $2.20 \mathrm{~g} \mathrm{~kg}^{-1}$ (Konya for CV5), $2.32 \mathrm{~g} \mathrm{~kg}^{-1}$ (2006 for CV5) and $2.53 \mathrm{~g} \mathrm{~kg}^{-1}$ (Ankara $\times 2006$ $\times$ CV5), respectively.

While these results were in agreement with the earlier reports by Allen et al. (1989), Nancy (1992), Tongel and Ayan (2010) and Turan et al. (2010), the values were lower than those obtained by Collins (1989), Jenking and Bottemley (1984) and Smith (1969). The differences in the content of $\mathrm{Mg}$ found in this study, compared with the literature data, could partly be explained by differences between forage species, levels of $\mathrm{Mg}$ in the soil, influences of the location and climate, a growth stage, the proportion of leaf and stem fractions collected for mineral analysis, and the season when forage sampling was performed (Khan et al. 2009, 2006).
Animals need $\mathrm{Mg}$ for skeletal growth, milk production, nerve impulse transmission, muscular control and the maintenance of enzyme systems (Lemus 2013). Herbage $\mathrm{Mg}$ concentrations are usually within the range of 0.08 to $0.30 \%$, and legumes generally have a higher concentration of Mg than grasses (Kacar 1972).

\section{CALCIUM (CA) CONTENT}

It was observed that the effects of the year, location, cultivar and year $\times$ location, location $\times$ cultivar, year $\times$ cultivar and location $\times$ year $\times$ cultivar interactions on the Ca content were highly significant $(p<0.01)$ (Table 3$)$. The $\mathrm{Ca}$ content was $16.04 \mathrm{~g} \mathrm{~kg}^{-1}$ in 2006 and $12.56 \mathrm{~g} \mathrm{~kg}^{-1}$ in 2007 (Table 5). In general, the Ca contents in Konya and Ankara provinces were found to be comparable; however, the Ca content in Konya (15.91 $\mathrm{g} \mathrm{kg}^{-1}$ ) was higher. When comparing the effects of the location $\times$ year interaction, the highest $\mathrm{Ca}$ content $\left(16.51 \mathrm{~g} \mathrm{~kg}^{-1}\right)$ was obtained for Ankara in 2006. Among the cultivars, CV4 had the highest $\mathrm{Ca}$ content $\left(16.39 \mathrm{~g} \mathrm{~kg}^{-1}\right)$. The highest $\mathrm{Ca}$ contents for the location $\times$ cultivar and year $\times$ cultivar interactions were obtained for CV4 in Konya $\left(15.55 \mathrm{~g} \mathrm{~kg}^{-1}\right)$ and CV5 in $2006\left(19.41 \mathrm{~g} \mathrm{~kg}^{-1}\right)$, respectively. The Ca contents for the location $\times$ year $\times$ cultivar interaction ranged 6.71 (Ankara $\times 2007 \times \mathrm{CV} 1)$ to $22.81 \mathrm{~g} \mathrm{~kg}^{-1}$ (Ankara $\times 2006 \times$ CV5). Similar results were reported by Tongel and Ayan (2010) who found that Ca contents of alfalfa hay ranged 1.08 to $2.33 \%$. Smith (1970) in a study on the influence of temperature on the chemical composition mentioned that $\mathrm{Ca}$ concentrations in alfalfa varied from 0.97 to $1.26 \%$. In another study, Ca concentrations ranged 1.55 to $1.89 \%$ in a cool/warm regime and a cool regime, respectively (Smith 1969).

Animals need Ca for skeletal growth, milk production, nerve impulse transmission, and the maintenance of enzyme systems (Lemus 2013). Forage Ca requirements of grazing ruminants are a subject of considerable debate as the requirement is influenced by the animal type, level of production, age and weight (Khan et al.2006). A forage for ruminants should contain at least $0.3 \% \mathrm{Ca}$ (Kidambi et al. 1989; Tejada et al. 1985). The alfalfa Ca values found in this study were sufficiently higher than the ruminant requirements and thus may be considered adequate for

TABLE 3. Analysis of variance with main effect and interaction effect of different factors (six alfalfa cultivars; two locations and two years) on protein and mineral contents

\begin{tabular}{|c|c|c|c|c|c|c|c|c|c|c|c|c|c|c|c|}
\hline Source & $\mathrm{PC}$ & $P$ & $K$ & $\mathrm{Mg}$ & $\mathrm{Ca}$ & $\mathrm{Na}$ & $\mathrm{Mn}$ & $\mathrm{Fe}$ & $\mathrm{Zn}$ & B & Mo & $\mathrm{Cu}$ & $\mathrm{Cr}$ & $\mathrm{Se}$ & Al \\
\hline Year $(\mathrm{Y})$ & ns & $* *$ & $* *$ & $* *$ & $* *$ & $* *$ & $* *$ & $* *$ & $* *$ & ns & $* *$ & ns & $*$ & $*$ & ns \\
\hline Genotype (G) & $* *$ & $* *$ & $* *$ & $* *$ & $* *$ & $* *$ & $* *$ & $* *$ & $* *$ & $* *$ & $* *$ & $* *$ & $* *$ & $*$ & ns \\
\hline $\mathrm{L} \times \mathrm{G}$ & ns & $* *$ & ns & $* *$ & $* *$ & $* *$ & $* *$ & $* *$ & $* *$ & $* *$ & $* *$ & ns & $* *$ & ns & $* *$ \\
\hline
\end{tabular}

F-test significance: $*: \mathrm{P} \leq 0.05 ; * *: \mathrm{P} \leq 0.01$; ns: not significant 
optimum performance of ruminants. Similar conclusions were also made by other researchers such as Khan et al. (2006) and Tongel and Ayan (2010).

\section{SODIUM (NA) CONTENT}

The results of the analysis of variance showed that the $\mathrm{Na}$ contents in alfalfa were significantly affected by the location, year, cultivar and location $\times$ year, location $\times$ cultivar, year $\times$ cultivar, and location $\times$ year $\times$ cultivar interactions $(p<0.01)$ (Table 3).

The Na content was $1.44 \mathrm{~g} \mathrm{~kg}^{-1}$ in 2006 and $2.66 \mathrm{~g} \mathrm{~kg}^{-1}$ in 2007 and was higher in Ankara than in Konya (Table $5)$. For the location $\times$ year interaction, the highest $\mathrm{Na}$ content (3.96 $\mathrm{g} \mathrm{kg}^{-1}$ ) was obtained for Ankara during 2007 growing season. The Na contents of the alfalfa cultivars ranged from $1.20 \mathrm{~g} \mathrm{~kg}^{-1}$ in CV5 to $2.78 \mathrm{~g} \mathrm{~kg}^{-1}$ in CV3. The highest $\mathrm{Na}$ contents for the location $\times$ cultivar and year $\times$ cultivar interactions were obtained for CV6 in Ankara (3.89 $\left.\mathrm{g} \mathrm{kg}^{-1}\right)$ and $\mathrm{CV} 3$ in 2007 (3.68 $\left.\mathrm{g} \mathrm{kg}^{-1}\right)$, respectively. The $\mathrm{Na}$ contents for the location $\times$ year $\times$ cultivar interaction ranged $0.96 \mathrm{~g} \mathrm{~kg}^{-1}($ Ankara $\times 2006 \times \mathrm{CV} 1)$ to $5.65 \mathrm{~g} \mathrm{~kg}^{-1}$ $($ Ankara $\times 2007 \times$ CV3).

Similar results were obtained by Walzl et al. (2011) who mentioned that $\mathrm{Na}$ contents in alfalfa ranged from 0.9 to $1.0 \mathrm{~g} \mathrm{~kg}^{-1}$. Turan et al. (2010) found that $\mathrm{Na}$ contents in different locations and at different boron application rates ranged in alfalfa from 880 to $1,090 \mathrm{mg} \mathrm{kg}^{-1}$. Kacar (1972) mentioned that herbage Na concentrations varied more than a thousand-fold, from 0.002 to $2.12 \%$ and any values between 0.05 and $1 \%$ would not be considered unusual. Animals need $\mathrm{Na}$ for glucose and amino acid transport, for retaining body fluids and maintaining acidbase balance (Lemus 2013). Khan et al. (2009) mentioned that, as quoted by other researchers, $\mathrm{Na}$ requirements for ruminants are debatable, yet the range from $1-4 \mathrm{~g} \mathrm{~kg}^{-1}$ is recommended. A dairy Holstein cow with milk production of $35 \mathrm{~kg} \mathrm{day}^{-1}$ needs $2.3 \mathrm{~g}$ of Na kg${ }^{-1}$ of dry matter herbage (NRC 2001). According to the results of the present study, the Na concentrations were low or equivalent to the levels recommended for optimal animal production.

\section{MICROELEMENTS}

The variance analysis showed statistically highly significant effects of the locations on the Mo contents in alfalfa hay (Table 3). The location effects were also statistically significant on the $\mathrm{Mn}, \mathrm{Zn}, \mathrm{B}$ and $\mathrm{Cu}$ contents. However, locations had no effects on the $\mathrm{Fe}, \mathrm{Cr}$, Se and $\mathrm{Al}$ contents. The year effects were highly significant on $\mathrm{Mn}$, $\mathrm{Fe}, \mathrm{Zn}$ and $\mathrm{Mo}$ and significant on $\mathrm{Cr}$ and $\mathrm{Se}$, but there were no effects on the $\mathrm{B}, \mathrm{Cu}$ and $\mathrm{Al}$ contents. The location $\times$ year interaction had statistically highly significant effects on $\mathrm{Mn}, \mathrm{Zn}$ and Mo, significant effects on $\mathrm{Cr}$ and $\mathrm{Al}$, but no effects on the $\mathrm{Fe}, \mathrm{B}, \mathrm{Cu}$, and Se contents. The cultivars had statistically highly significant effects on the contents of all microelements, except Al. The location $\times$ cultivar interaction had statistically highly significant effects on the contents of all microelements, except $\mathrm{Cu}$ and $\mathrm{Se}$. The year $\times$ cultivar interaction had highly significant effects on the contents of all microelements, except Al, which was affected significantly. Lastly, the location $x$ year $x$ cultivar interaction had highly significant effects on $\mathrm{Mn}$, $\mathrm{Fe}, \mathrm{Zn}, \mathrm{B}, \mathrm{Mo}, \mathrm{Cr}$ and $\mathrm{Se}$ and a significant effect on $\mathrm{Al}$, but no effect on the $\mathrm{Cu}$ content in alfalfa hay (Table 3 ).

The manganese $(\mathrm{Mn})$ contents of alfalfa hay ranged 15.4 to $54.3 \mathrm{mg} \mathrm{kg}^{-1}$, with an average of $34.60 \mathrm{mg} \mathrm{kg}^{-1}$ (Table 5). Similar results on Mn contents of alfalfa were reported by Walzl et al. (2011) (43.5 to $47.7 \mathrm{mg} \mathrm{kg}^{-1}$ ), Turan et al. (2010) (8.0 to $\left.33.0 \mathrm{mg} \mathrm{kg}^{-1}\right)$ and Tongel and Ayan (2010) (13.10-39.54 mg kg-1). A dairy Holstein cow with milk production of $35 \mathrm{~kg}^{-1 a y^{-1}}$ needs $15.0 \mathrm{mg}$ of $\mathrm{Mn}$ $\mathrm{kg}^{-1}$ of dry matter herbage (NRC 2001).

The iron $(\mathrm{Fe})$ contents in alfalfa hay ranged 44.3 to $92.7 \mathrm{mg} \mathrm{kg}^{-1}$, with an average of $69.7 \mathrm{mg} \mathrm{kg}^{-1}$ (Table $5)$. Almost similar results were reported by Walzl et al. (2011) who found that Fe contents in alfalfa hay ranged from 63.1 to $69.8 \mathrm{mg} \mathrm{kg}^{-1}$. However, Turan et al. (2010) found that $\mathrm{Fe}$ contents of alfalfa varied from 62 to 188 $\mathrm{mg} \mathrm{kg}^{-1}$, which is higher than the results of this study. Even higher results were reported by Tongel and Ayan (2010) who mentioned that Fe contents of alfalfa were between 209.3 and $343.1 \mathrm{mg} \mathrm{kg}^{-1}$ and by Scholtz et al. (2009) who noted that Fe contents in alfalfa ranged 149 to $3,138 \mathrm{mg} \mathrm{kg}^{-1}$. According to Kacar (1972), soil pH is the most important factor governing Fe uptake. Also, deficiency of $\mathrm{Fe}$ is due to low availability of insoluble oxides and phosphates and therefore, is most likely to occur on calcareous soils. Other researchers mentioned that differences in $\mathrm{Fe}$ contents could be partly explained by variations in the content of $\mathrm{Fe}$ in soils and in climatic conditions between locations (Khan et al. 2006). The zinc $(\mathrm{Zn})$ contents in alfalfa hay ranged from 24.6 to $121.9 \mathrm{mg} \mathrm{kg}^{-1}$, with an average of $56.4 \mathrm{mg} \mathrm{kg}^{-1}$ (Table $6)$. These findings were similar to the ranges reported by other researchers for alfalfa cultivars, 24.89-83.01 mg $\mathrm{kg}^{-1}$ (Tongel \& Ayan 2010), 25-85 $\mathrm{mg} \mathrm{kg}^{-1}$ (Turan et al. 2010) and 23-75 $\mathrm{mg} \mathrm{kg}^{-1}$ (Scholtz et al. 2009). However, Walzl et al. (2010) found that the $\mathrm{Zn}$ content of alfalfa varied from 22.9 to $25.0 \mathrm{mg} \mathrm{kg}{ }^{-1}$, which is lower than the results of this study. A dairy Holstein cow with milk production of $35 \mathrm{~kg}$ day ${ }^{-1}$ needs $14 \mathrm{mg}$ of $\mathrm{Zn} \mathrm{kg}^{-1}$ of dry matter herbage (NRC 2001). Dietary requirements of ruminants for $\mathrm{Zn}$ ranged 12 to $30 \mathrm{mg} \mathrm{kg}^{-1}$ (Khan et al. 2009). Thus, the alfalfa $\mathrm{Zn}$ values found in this study were considered adequate for ruminants.

The boron (B) contents in alfalfa hay ranged from 46.4 to $85.4 \mathrm{mg} \mathrm{kg}^{-1}$, with an average of $65.4 \mathrm{mg} \mathrm{kg}^{-1}$ (Table 6). The B values in this study were higher than the 18.8-19.6 $\mathrm{mg} \mathrm{kg}^{-1}$ range reported by Walzl et al. (2011), but similar to the $30-52 \mathrm{mg} \mathrm{kg}^{-1}$ range reported by Smith (1969) and the $37-52 \mathrm{mg} \mathrm{kg}^{-1}$ range reported by Caldwell et al. (1969). The molybdenum (Mo) contents in alfalfa hay ranged from 0.50 to $6.13 \mathrm{mg} \mathrm{kg}^{-1}$, with an average of $1.94 \mathrm{mg} \mathrm{kg}^{-1}$ (Table 6). These results agree with earlier reports by Walzl et al. (2011) who found that Mo contents 


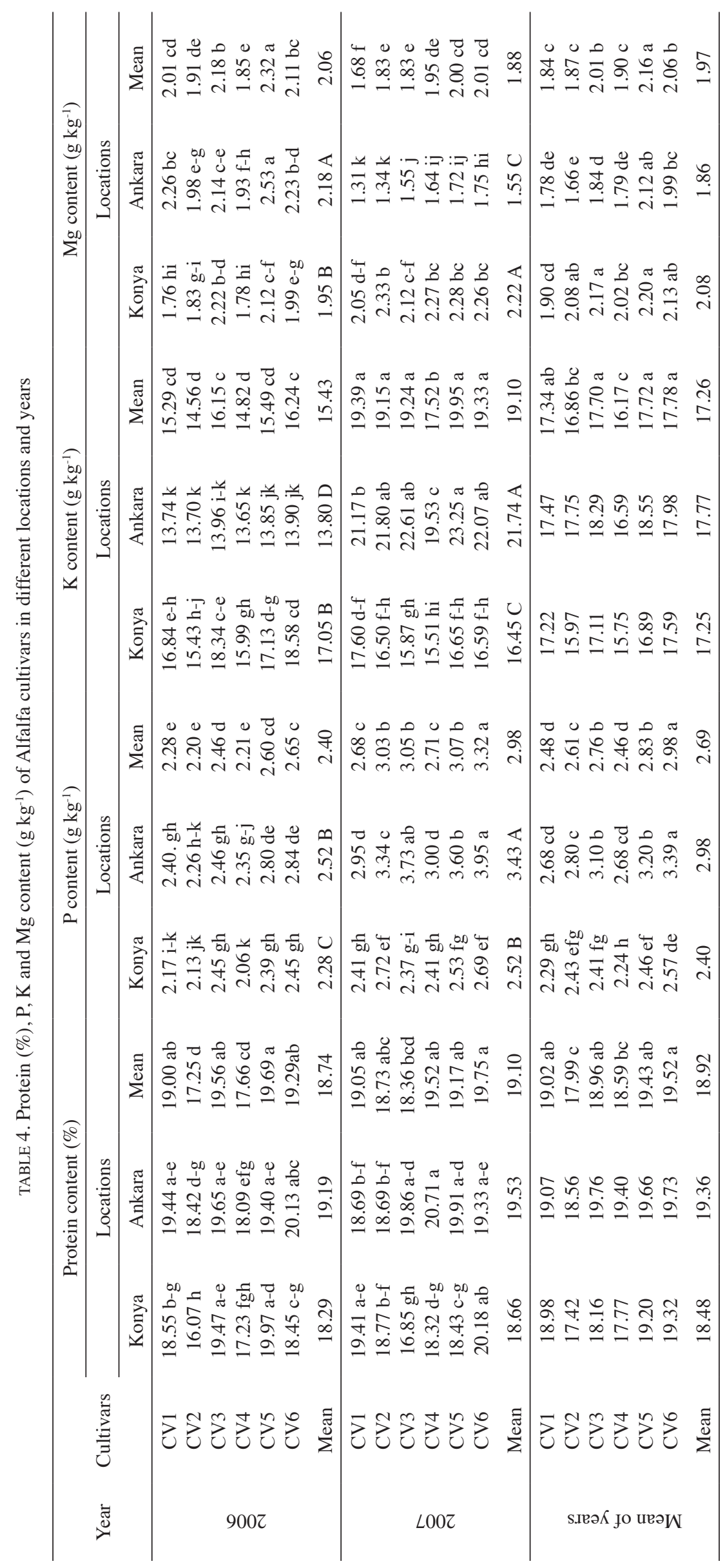




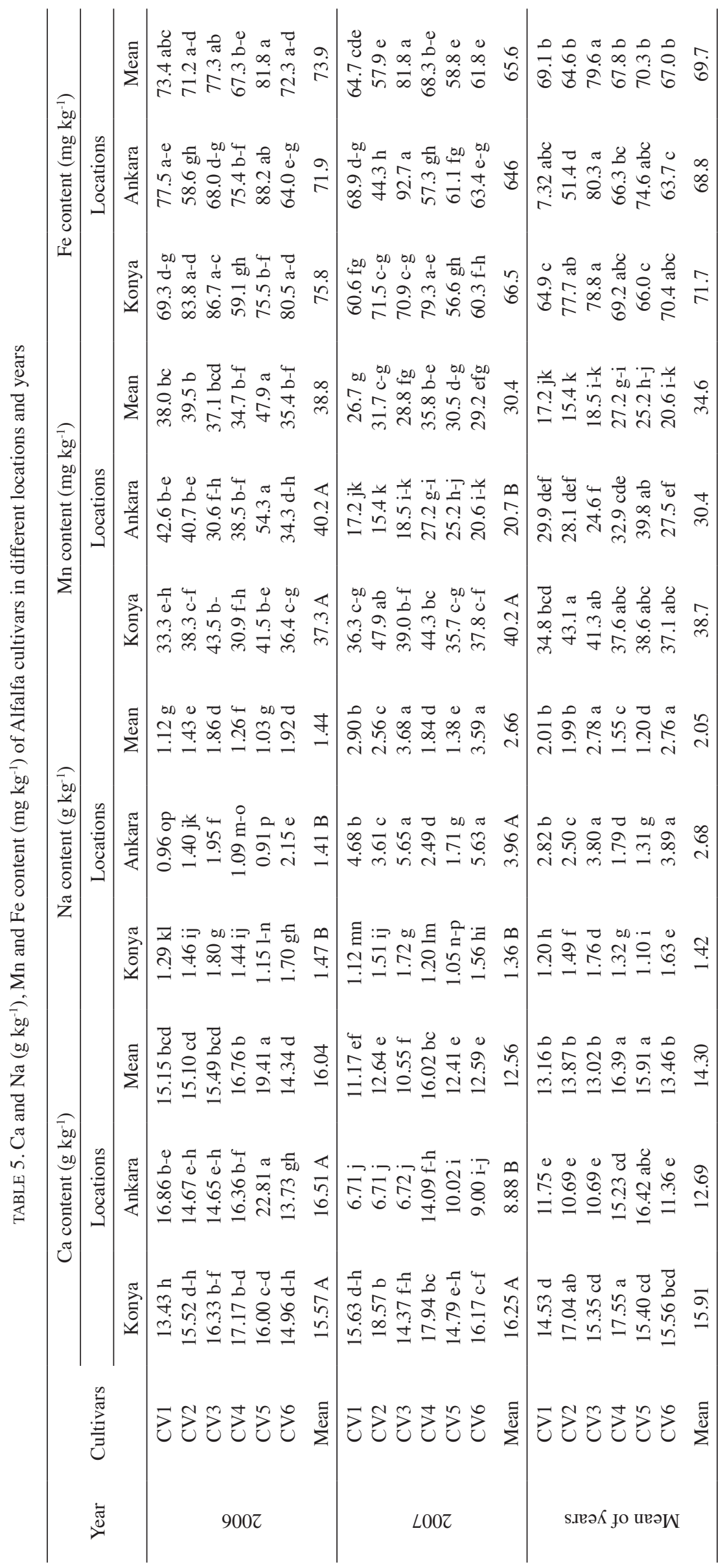




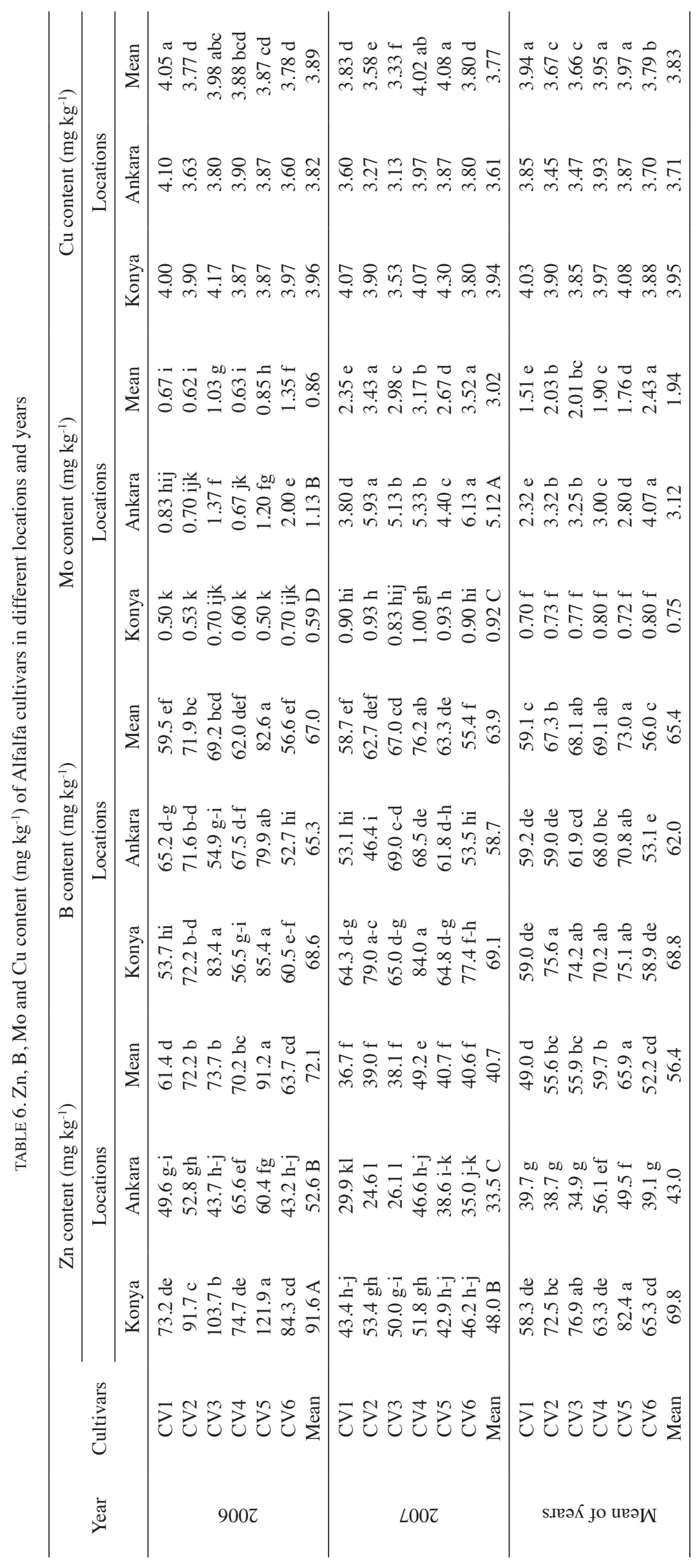




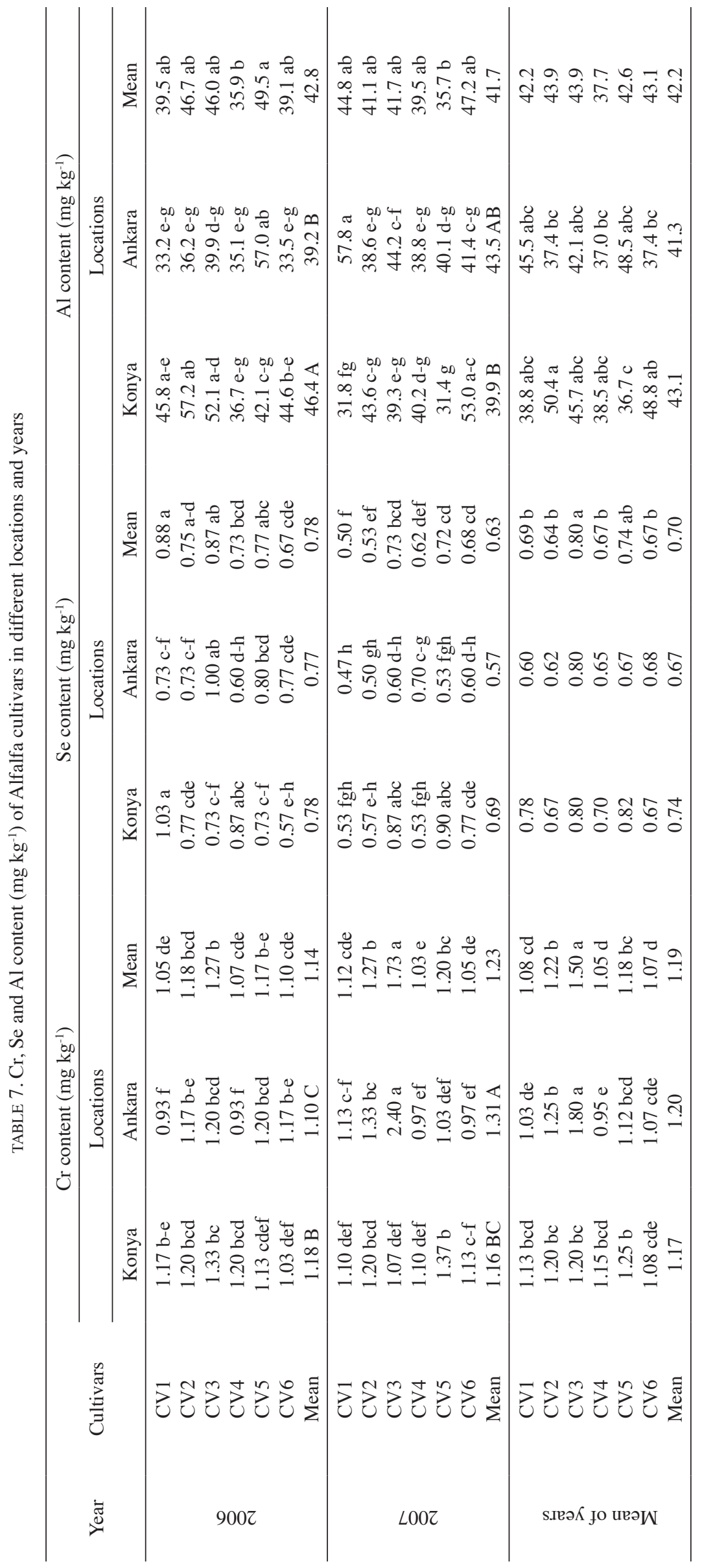


in alfalfa ranged from 0.3 to $1.4 \mathrm{mg} \mathrm{kg}^{-1}$ and by Caldwell et al. (1969) who found that Mo contents ranged 1.6-1.9 $\mathrm{mg} \mathrm{kg}^{-1}$. The Mo concentrations in 24 alfalfa samples from New Jersey farms ranged less than 0.1 to $1.44 \mathrm{mg} \mathrm{kg}^{-1}$, with an average of $0.88 \mathrm{mg} \mathrm{kg}^{-1}$ (Kacar 1972).

The copper $(\mathrm{Cu})$ contents in alfalfa hay ranged from 3.13 to $4.17 \mathrm{mg} \mathrm{kg}^{-1}$, with an average of $3.83 \mathrm{mg} \mathrm{kg}^{-1}$ (Table 6). Similar results were obtained by Smith (1969) who found that $\mathrm{Cu}$ contents in the Vernal alfalfa herbage harvested at first flower, following growth under cool and warm temperatures, varied from 3.0 to $4.0 \mathrm{mg} \mathrm{kg}^{-1}$. However, some previous studies have presented conflicting results. Thus, higher values were obtained by Turan et al. (2010) (5-20 mg kg-1) and Tongel and Ayan (2010) (from 3.08 to $15.69 \mathrm{mg} \mathrm{kg}^{-1}$ ). Also, Walzl et al. (2011) obtained $\mathrm{Cu}$ contents ranging from 5.8 to $7.4 \mathrm{mg} \mathrm{kg}^{-1}$. The differences among $\mathrm{Cu}$ values reported earlier could be partly explained by genotypic differences, the vegetative parts used, a stage of maturity, levels of available $\mathrm{Cu}$ in the soil and soil pH (Khan et al. 2006). The chromium $(\mathrm{Cr})$ contents in alfalfa hay ranged from 0.93 to $2.40 \mathrm{mg}$ $\mathrm{kg}^{-1}$, with an average of $1.19 \mathrm{mg} \mathrm{kg}^{-1}$ (Table 7). Walzl et al. (2011) showed a Cr content of $0.2 \mathrm{mg} \mathrm{kg}^{-1}$ in alfalfa, which is lower than our results. The selenium (Se) contents in alfalfa hay ranged 0.77 to $1.03 \mathrm{mg} \mathrm{kg}^{-1}$, with an average of $0.70 \mathrm{mg} \mathrm{kg}^{-1}$ (Table 7). However, Se is important in animal nutrition because its trace amounts can prevent muscular dystrophy, while higher levels can cause a disease called blind staggers or alkali disease (Kacar 1972). The aluminum (Al) contents in alfalfa hay ranged from 31.2 to $57.8 \mathrm{mg} \mathrm{kg}^{-1}$, with an average of $42.2 \mathrm{mg} \mathrm{kg}^{-1}$ (Table 7). This agrees with an earlier report by Smith (1969) who found that $\mathrm{Al}$ contents in alfalfa ranged from 41 to $49 \mathrm{mg}$ $\mathrm{kg}^{-1}$.

\section{CONCLUSION}

We found significant differences among the cultivars with regard to the contents of protein and several mineral elements. The importance of the location $\times$ year $\times$ cultivar interaction demonstrated that an appropriate cultivar should be selected or each region. Furthermore, since the protein content varied depending on the year, we recommend that protein and mineral contents are analyzed every year to prepare an accurate ration for feeding livestock. The levels of mineral elements in alfalfa hay were sufficient for many livestock species. The high crude protein content and mineral element levels in alfalfa hay, meeting the needs of many livestock species, are important for organic livestock farmers. In particular, alfalfa hay with high protein and mineral contents can be sufficient, without any supplementary foods, when alfalfa is under a snow cover during winter in organic livestock husbandry enterprises. Due to the fact that the crude protein and mineral element contents differed among the cultivars, increasing those should be one of the main objectives in future alfalfa breeding programs, along with improving the hay yield.

\section{REFERENCES}

AACC. 1990. Approved Methods of the American Association of Cereal Chemists. 8th ed. St. Paul, MN, USA: American Association of Cereal Chemists.

Acar, R., Ozcan, M.M., Kanbur, G. \& Dursun, N., 2012. Some physico-chemical properties of edible and forage watermelon seeds. Iran J. Chem. Chem. Eng. 31(4): 41-47.

Acar, R., Demiryurek, M., Okur, M. \& Bitgi, S. 2011. An investigation of artificial pasture establishment under dryland conditions. African Journal of Biotechnology 10(5): 764-769.

Akca Pelen, M., Kızıl Aydemir, S., Sezer, N. \& Y1lmaz, K. 2013. Examination of registered alfalfa (Medicago sativa L.) varieties efficiency results obtained from variety registration trials and importance of these varieties in present seed growing. Turkiye 10. Tarla Bitkileri Kongresi, Konya 3: 189-194 (in Turkish).

Alien, V.G., Hamilton, L.A., Wolf, D.D., Fontenot, J.P., Terrill, T.H.\& Notter, D.R. 1986. Yield and regrowth characteristics of alfalfa grazed with sheep. II. Summer Grazing. Agronomy Journal 78: 979-985.

Aslan, M. 2017. Variation of some seed trace element contents in grass pea (Lathyrus sativus L.) genotypes from Turkey. Fresenius Environmental Bulletin 26(5): 3676-3684.

Avci, M.A., Ozkose, A. \& Tamkoc, A. 2013. Determination of yield and quality characteristics of alfalfa (Medicago sativa L.) varieties grown in different locations. Journal of Animal and Veterinary Advances 12(4): 487-490.

Avcioglu, R., Geren, H., Tamkoc, A. \& Karadag, Y. 2009. Yonca (Medicago sp. L.). In Yembitkileri, edited by Avcioglu, R., Hatipoglu, R. \& Karadag, Y. Republic of Turkey, Ministry of Agriculture and Rural Affairs, Izmir, Turkey. 2: 296-316 (in Turkish).

Aydin, I. \& Tosun, F. 1991. A research on dry matter yield, crude protein content and yield of common vetch (Vicia sativa L.) + some cereal species grown under Samsun ecological conditions. Proceedings of Congress of Pasture and Forage Crops, (CPFC'91), Bornova-Izmir. pp: 332-340.

Caldwell, A.C., Seim, E.C. \& Rehm, G.W. 1969. Sulfur effects on the elemental composition of Alfalfa (Medicago sativa L.) and Corn (Zea mays L.). Agronomy Journal 61: 632-634.

Ceylan, S., Soya, H., Budak, B., Akdemir, H. \& Colak Esetlili, B. 2009. Effect of zinc on yield and some related traits of alfalfa. Turkish Journal of Field Crops 14(2): 136-143.

Collins, M. \& Taylor, T.H. 1980. Yield and quality of alfalfa harvested during autumn and winter and harvest effects on the spring crop. Agronomy Journal 71: 839-844.

Collins, M. 1989. Mineral concentrations in whole crop and pressed forage of three legumes. Agronomy Journal 81: 901-906.

Haby, V.A., Davis, J.V. \& Leonard, A.T. 1999. Response of over seeded alfalfa and bermudagrass to alfalfa row spacing and nitrogen rate. Agronomy Journal 91: 902-910.

Janghorbani, M., Roberts, S. \& Jackson, T.L. 1975. Relationship of exchangeable acidity to yield and chemical composition of alfalfa. Agronomy Journal 67: 350-354.

Jenkins, M.B. \& Bottomley, P.J. 1984. Seasonal response of uninoculated alfalfa to $\mathrm{n}$ fertilizer: Soil $\mathrm{N}$, nodule turnover, and symbiotic effectiveness of Rhizobium meliloti. Agronomy Journal 76: 959-963.

Kacar, B. 1994. Toprak Analizleri [Soil Analysis (in English)]. Ankara Universitesi, Ziraat Fakultesi Egitim, Arastırma ve Gelistirme Vakfı Yayınları No:3. Ankara (in Turkish). 
Kacar, B. 1972. Chemical analysis of plant and soil-II, Plant analysis. Ankara University, Faculty of Agriculture, Ankara (Unpublished).

Kahraman, A. 2017. Nutritional value and foliar fertilization in soybean. J.Elem. 22(1): 55-66.

Karadag, Y., Iptas, S., Kir, H. \& Akbay, S. 2011. The determination of the yield and quality characteristics of some alfalfa cultivars under Tokat-Kazova conditions. Turkiye 9. Tarla Bitkileri Kongresi, Bursa 3, 1962-1965 (in Turkish).

Khan, Z.I., Ashraf, M. \& Valeem, E.E. 2006. Forage mineral status evaluation: The influence of pastures Pak. J. Bot. 38(4): 1043-1054.

Khan, Z.I., Ashraf, M., Ahmad, K., Ahmad, N., Danish, M. \& Valeem, E.E. 2009. Evaluation of mineral composition of forages for grazing ruminants in Pakistan. Pak.J. Bot. 41(5): 2465-2476.

Kidambi, S.P., Matches, A.G. \& Gricgs, T.C. 1989. Variability for $\mathrm{Ca}, \mathrm{Mg}, \mathrm{K}, \mathrm{Cu}, \mathrm{Zn}$, and $\mathrm{K} /(\mathrm{Ca}+\mathrm{Mg})$ ratio among 3 wheatgrasses and sainfoin on the southern high plains. Journal of Range Management 42(4): 316-322.

Lemus, R. 2013. What are the mineral concentrations of forage? Mississippi State University, 6(2), 1-2 http://msucares.com/ crops/forages/newsletters/13/20130201.pdf.

Nancy, J. 1992. Digestibility and mineral utilization of six sequential alfalfa cutting by wethers. Ph.D. thesis, New Mexico State University, Las Cruces, New Mexico (Unpublished).

National Research Council (NRC). 2001. Nutrient Requirements of Dairy Cattle. Seventh Revised Edition. Washington: National Academy Press.

Orloff, S.B. \& Putnam, D.H. 2007. Forage quality testing. In Irrigated Alfalfa Management in Mediterranean and Desert Zones. Chapter 16, edited by Summers, C.G. \& Putnam, D.H. Oakland: University of California Agriculture and Natural Resources Publication 8302. http://alfalfa.ucdavis. edu/Irrigated Alfalfa. Accessed on 13 March 2015.

Ozcan, M. 2004. Mineral contents of some plants used as condiments in Turkey. Food Chemistry 84: 437-440.

Ozkose, A. 2013. Determination of yield and yield components of fodder beet (Beta vulgaris L.var. rapacea Koch.) cultivars under the Konya region conditions. International Journal of Biological, Veterinary, Agricultural and Food Engineering 7(12): 826-829.

Pirhofer-Walzl, K., Søegaard, K., Høgh-Jensen, H., Eriksen, J., Sanderson, M.A., Rasmussen, J. \& Rasmussen, J. 2011. Forage herbs improve mineral composition of grassland herbage. Grass and Forage Science 66: 415-423.

Sabancı, C.O., Ertus, M.M. \& Zorer Celebi,Z. 2013. Collection, conservation and evaluation for forage yield of alfalfa landraces grown in East Anatolia. Turkish Journal of Field Crops 18(1): 46-51.
Scholtz, G.D.J., van Der Merwe, H.J. \& Tylutki, T.P. 2009. The nutritive value of South African Medicago sativa L. hay. South African Journal of Animal Science 39: 179-182.

Smith, D. 1970. Influence of temperature on the yield and chemical composition of five forage legume species. Agronomy Journal 62: 520-523.

Smith, D. 1969. Influence of temperature on the yield and chemical composition of 'vernal' alfalfa at first flower, Agronomy Journal 61: 470-472.

Tejada, R., McDowell, L.R., Martin, F.G. \& Conrad, J.H. 1985. Mineral element analyses of various tropical forages in Guatemala and their relationship to soil concentrations. Nutr. Rep. Int. 32: 313-323.

Tongel, M.O. \& Ayan, I. 2010. Nutritional contents and yield performances of lucerne (Medicago sativa L.) cultivars in Southern Black Sea shores. Journal of Animal and Veterinary Advances 9(15): 2067-2073.

Turan, M., Ketterings, Q.M., Gunes, A., Ataoglu, N., Esringu, A., Bilgili, A.V. \& Huang, Y.H. 2010. Boron fertilization of Mediterranean aridisols improves lucerne (Medicago sativa L.) yields and quality. Acta Agriculturae Scandinavica, Section B - Soil \& Plant Science 60(5): 427-436.

Ulgen, N. \& Yurtsever, N. 1974. Turkiye gubre ve gubreleme rehberi. Toprak ve GubreAraştırma Enstitusu Teknik Yayınlar Serisi, 28, Kemal Matbaası, Ankara (in Turkish).

Underwood, E.J. 1981. The Mineral Nutrition of Livestock. Slough, England: Commonwealth Agricultural Bureaux. p. 10.

Wedin, W.F., Burger, A.W. \& Ahlgren, H.L. 1956. Effect of soil type, fertilization, and stage of growth on yield, chemical composition, and biological value of ladino clover (Trifolium repens L.) and alfalfa (Medicago sativa L.). Agronomy Journal 48(4): 147-152.

Selçuk Üniversitesi (Selcuk University)

Ardıçlı Mahallesi, İsmetpaşa Cad

42250 Selçuklu/Konya

Turkey

*Corresponding author; email: aozkose@selcuk.edu.tr

Received: 7 May 2015

Accepted: 6 October 2017 